\title{
The Legal Consequence Of The Judge Decision In The Case Of Children Criminal Justice Which Do Not Based On Society Research From Society Supervisor (Studies on Settlement Case of Children Crime In State Court of Cirebon)
}

\author{
Tasmo $^{1}$ and Rahmat Bowo Suharto ${ }^{2}$
}

Abstract. This study to answer the question: 1) The legal consequences of the Juvenile Judge decision who do not based the Society Research (Litmas) of Society Supervisor $(P K)$ in the State Court of Cirebon, 2) The value of justice verdict child in considering Society Research (Litmas) of Society Supervisor (PK) in the State Court of Cirebon.

The approach used in this study is a sociological juridical approach. The kind of this research is descriptive analysis. Data were collected by interview and literature method. The method used by researchers is sociological approach juridical law and specification in this study were included descriptive analysis. As for sources and types of data in this study are primary data obtained from interviews with field studies State Court of Cirebon, and secondary data obtained from the study of literature.

The final conclusion is: 1) The legal consequences of the judge's decision not to consider children who Litmas Results PK Bapas under Article 60 of Child Law Criminal Justice System, child verdict is declared null and void, and the cancellation do not require cancellation; 2) Society Research (Litmas) Society Supervisors $(P K)$ Correctional Center did not bring a positive impact to deliver a fair verdict and best for the child, when the judge makes it just as a mere formality and not as consideration verdict. Put forward suggestions: 1) It should be implemented in law changes SPPA clearly so Litmas PK Bapas not only as a formal requirement child judges in decisions; 2)Institutions should set up an oversight judge to judge that the judge's ruling the child can be declared as null and void the decision, and the judge supervision should stipulate that convicted child can not be executed by the Public Prosecutor.

Keywords: Law Effects; Judge Decision; Child Crime; Society Research; Society Supervisor.

\section{Introduction}

Indonesia as a state of law should play a role in all areas of life, both in the life of the nation and the Republic of Indonesia as well as in the lives of its citizens. It aims to create their security and order, justice and prosperity in life society, nation, and state and so that the law is enforced means that the law must be respected and obeyed by everyone without exception either by all citizens, law enforcement agencies as well as by the state authorities, all actions must be guided by the law.

Law enforcement itself is an attempt to enforce the legal norms of the real as a code of conduct in traffic law relationships in the life of society, nation and state, is expected to encourage creativity and active role in building a society countries, especially in

\footnotetext{
${ }^{1}$ Student of Master of Law, Universitas Islam Sultan Agung Semarang and Police member, email: tasmoprakarsa@gmail.com

${ }^{2}$ Lecturer of Master of Law, Sultan Agung Islamic University (UNISSULA), Semarang
} 
ensuring the independence of the Human Rights for are fundamental rights that are naturally inherent in human beings, and nature universal. Therefore, it must be protected, respected, and defended and should not be ignored, reduced or taken away by anyone, including law enforcement against Children in conflict with the law (ABH). Son of a mandate once the gift of God Almighty, even children as the most valuable treasure of wealth compared to other possessions. Children as the mandate of God must always be preserved and protected as in the child inherent dignity, dignity, and rights as a human being which must be upheld. Kids has a very strategic position in the life of the nation ${ }^{3}$, and the child's rights are part of human rights contained in 1945 and the United Nations Convention on the Rights of the Child. ${ }^{4}$

Regarding the criminal punishment against children, Mardjono Reksodiputro more likely to use coaching outside of the institution (treatment in society) as a first step in the formation of child offenders. ${ }^{5}$ Rather than be developed in prison or in other words the form of imprisonment punishments carried out in Penitentiary.

In the settlement process of the child, the child's interests should be prioritized and receive special protection. All the activities of law enforcement officers conducted within the framework of juvenile justice should be based for the welfare of the child and the child's interests. The purpose of juvenile justice can not be separated from the main purpose for the welfare of the child which is basically an integral part of the social welfare. The juvenile justice process, from the investigation to the sanctions and their placement in correctional institutions, should consider social research report. The ultimate goal is to be able to assist the judge in deciding the fate of the child, where the situations described in the Society Research could be one of the judges consideration sociological considerations.

Based on the background of the problems mentioned above, then the problem can be formulated as follows: How the legal consequences of the decision of the Juvenile Judge who do not consider the results of Society Research (Litmas) Society Supervisor (PK) in State Court of Cirebon?; How to value fairness in considering the child's verdict Society Research (Litmas) Society Supervisor (PK) in State Court of Cirebon?

\section{Research methods}

The approach used in this study is a sociological juridical approach. Sociological juridical approach is to identify and conceptualize law as a social institution that is real and functional in a real life system. ${ }^{6}$ The kind of this research is descriptive analysis. According to Whitney, the descriptive method is the fact finding with the correct interpretation. ${ }^{7}$ The purpose of descriptive research is to describe precisely, the nature of the individual, a symptom, condition or specific groups.

\footnotetext{
${ }^{3}$ Romi Asmara, et al., 2008, "Kejahatan Kesusilaan Terhadap Ana (Suatu Tinjauan Perlindungan Hukum Terhadap Anak Perempuan Korban Kejahatan Kesusilaan Di Kota Lhokseumawe)”, Jurnal Pasai, Vol. II, No. 2, September, 2008, p. 70.

4 Lukman Hakim and Nainggolan 2006, "Masalah Perlindungan Hukum Terhadap Anak", Journal of Equality, Vol. 10, No. 2, August 2006, p. 90. See also Dewi Nurul Musjtari, "Memberikan Hak Memilih Agama Sebagai Upaya Perlindungan Anak", Journal Constitution, Vol. 3, No. 2, May 2006, p. 25.

${ }^{5}$ Mardjono Reksodiputro, 1997, Kriminologi dan Sistem Peradilan Pidana, Pusat Pelayanan Keadilan dan Pengabdian Hukum University of Indonesia, Jakarta, p. 116.

${ }^{6}$ Soerjono Soekanto, 1986, Pengantar Penelitian Hukum, University of Indonesia Press, Jakarta, p. 51.

${ }^{7}$ Soejono and Abdurahman, 1999, Metode Penelitian, Rieneka Citra, Jakarta, p. 21
} 


\section{Results and Discussion}

\subsection{The legal consequences of the decision of the Juvenile Judge who do not consider the results of Society Research (Litmas) Society Supervisor (PK) in State Court of Cirebon}

In the settlement process of the child, the child's interests should in priority and receive special protection. According Sudarto, all the activities of law enforcement officers conducted within the framework of juvenile justice is being done by the police, prosecutor, judge or other officer-officials should be based on a principle for the welfare of the child and the child's interests ${ }^{8}$, Son is "a generation who will one day Become our national leader", said Benjamin Fine. ${ }^{9}$ Barda Nawawi Arief said the purpose of juvenile justice and thought cannot be separated from the main purpose for the welfare of the child which is essentially an integral part of social welfare ${ }^{10}$,

Special protection to children perpetrators of criminal acts, ranging from the investigation to the sanctions and placing it in the Penitentiary, should consider the Research Report Society child made by Officers Society.

Article 60 of Act of SPPA paragraph (3) and (4) states that: The judge shall consider the report of the Supervisor of Society social research before verdict of the case, in terms of society research reports were not considered in the Court decision, the decision is null and void. The explanatory paragraph (4) of Article 60 of Act of SPPA asserted, that void in this provision is without requested to be canceled and the verdict does not have binding legal force.

The same thing is also contained in the United Nations Standard Minimum Rules For The Administration of Juvenile Justice (the Beijing Rules) adopted by the UN Resolution No.04 / 33 November 29, 1985 states in rule 16. The social inspection reports $16.2^{11}$ :

In all cases except those involving violations of law violations are minor, before the authorities legally provide the release Last before legal verdict handed down, the background and the circumstances in which the child was alive or circumstances under which the violation of the law has been will be investigated properly done so that facilitate decision legal decision of the case by the legal authorities.

The Society Research made by the Society Supervisor is only made once for one case a child against the perpetrators of the child, in the sense in which the Society Research the same used in any stage of the settlement of a criminal case, but the essence Society Research has a role or utilization different in each stage. Where the utilization of Society Research conducted and created by the Society Supervisor in each stage of the examination of a criminal case the child is as follows: Investigations phase; Prosecution phase; Trial phase.

Thus, the Society Research conducted and reported by Society Supervisor useful for all stages of the criminal justice through which the child, particularly in the Act of SPPA felt at all at this stage of the proceedings. Society Research conducted and created by Supervisor Society of children do or beneficial to provide assistance to investigators,

\footnotetext{
${ }^{8}$ Sudarto, 1996, Kapita Selekta Hukum Pidana, Alumni, Bandung, p. 140.

${ }^{9}$ Romli Atmasasmita, 1985, Problem Kenakalan Anak (Remaja), Armico, Bandung, p. 7.

${ }^{10}$ Muladi, and Barda Nawawi Arief, 1992, Bunga Rampai Hukum Pidana, Alumni, Bandung, p. 111.

${ }^{11}$ Purniati, tt, Analisa Situasi Sistem Peradilan Pidana Anak (Juvenile Justice System) di Indonesia, Criminology Departement Fakulty of Social and Politic Science University of Indonesia, Depok, p. 250.
} 
prosecutors, and judges for the purpose of examination in the trial process. In addition to the benefit of special protection against child offenders, ranging from the investigation until the criminal sanctions should consider the report made by the Society Research from Society Supervisor. Thus, in the case of children, consideration used judges to decide the case is not merely legal considerations, but is also used are social considerations with a view to action being dropped really useful and consider the best interests of children. The judge's ruling will affect the next life of the child is concerned, therefore, the judge should be quite certain, that the decision taken will be able to be one solid basis for restoring and taking the child toward a better future to develop themselves as responsible citizens for family life, state and nation. The Society Research but is also used are social considerations with a view to action being dropped really useful and consider the best interests of the child. The judge's ruling will affect the next life of the child is concerned, therefore, the judge should be quite certain, that the decision taken will be able to be one solid basis for restoring and taking the child toward a better future to develop themselves as responsible citizens for family life, state and nation. The Society Research but is also used are social considerations with a view to action being dropped really useful and consider the best interests of the child. The judge's ruling will affect the next life of the child is concerned, therefore, the judge should be quite certain, that the decision taken will be able to be one solid basis for restoring and taking the child toward a better future to develop themselves as responsible citizens for family life, state and nation. The Society Research that the decision taken will be able to be one solid basis for restoring and taking the child toward a better future to develop themselves as responsible citizens to family life, state and nation. The Society Research that the decision taken will be able to be one solid basis for restoring and taking the child toward a better future to develop themselves as responsible citizens to family life, state and nation. The Society Research conducted by Supervising Social expected to provide an overview on the background of the child offender and other matters to be taken into consideration in deciding the law enforcement "fate" of the child. ${ }^{12}$

So important and its benefits Research Report of Society Supervisor (PK) Bapas in the juvenile justice process, only $3 \times 24$ hours PK Bapas must submit a report Litmas to the investigator, and report Litmas PK Bapas will be taken into consideration by the Prosecution and Judge. However, as to whether the Bapas PK Litmas balance used as the basis by law enforcement children. The legal consequences of the judge's decision not to consider children who Litmas Results PK Bapas Article 60 of Act of SPPA as has been stated above, the child's verdict null and void, and Cancellation does not require a cancellation, since the decision does not have binding legal force.

\subsection{The Value of Justice In Considering The Child's Verdict Society Research (Litmas) of Society Supervisor (PK) in State Court of Cirebon}

Juvenile justice organized with the aim to re-educate and improve the attitude and the protection of children so that he can leave the bad behavior that he always did. Hence, in this case the examination process child, the child's interests should be prioritized and receive special protection. Act of SPPA as repeatedly stated above, shall consider

${ }^{12}$ Results Interview with State Court of Cirebon, on February 27, 2020, 13:45 pm 
the Report of Litmas PK Bapas, and if it is passed, then the verdict is declared null and void by without any cancellation.

Interference with the judiciary in the lives of children and families always aimed for tackle adverse circumstances that happen to children, such as child criminality, abandoned children and exploitation of children. The development of modern flow in criminal law that focuses on criminal, known for their individualization and differentiation of punishment, sentencing in accordance with state of being criminal, the handling of delinquent child offenders through juvenile justice, arranged so that children are not included in the prison house that just makes them worse than before. All activities are conducted within the framework of juvenile justice does carried out by the police, prosecutor, judge or other officials, must be based on a principle for the welfare of the child and the child's interests.

Judges consider Society Research Report made by the Society Supervisor Child settlement process. According to informants interviewed that in the settlement of children, "Judge always consider the conclusions or suggestions from Society Supervisor in imposing sanctions / criminal for children are many other factors to be considered by the judge, Litmas an absolute requirement there so it should be considered "Will but when viewed in the decision made Judge social studies report only a formal requirement for the judge in meeting provision of juvenile justice legislation, as mentioned in the ruling only by considering Litmas made social counselors attached State Court of Cirebon decision No. 07 / Pid.Sus.Anak / 2015 / PN.Cbn, clearly does not portray that the Judge's decision to use Litmas. Litmas only used as complementary verdict without visible substance of the Litmas ${ }^{13}$,

The value of justice in considering the child's verdict Society Research (Litmas) Society Supervisors (PK) Bapas giving instructions for the judge of the action or what punishment should inflicted on children with attention delinquency, the relationship of parent and child, family's socioeconomic situation, family relations and child on the surrounding environment, but Litmas Bapas $P K$ does not bring positive impact to deliver a fair verdict and best for the child, when the judge makes the Litmas PK Bapas not only as a mere formality for consideration decision.

\section{Closing}

\subsection{Conclusion}

Based on the previous description authors to conclude that:

- The legal consequences of the judge's decision not to consider children who Litmas Results PK Bapas under Article 60 of Child Law Criminal Justice System, child verdict is declared null and void, and Cancellation does not require a cancellation, since the decision does not have binding legal force. However, this article does not explicitly regulate what criteria judges did not consider Litmas PK Bapas, so even if there is only the phrase "Litmas created considering social counselors attached in State Court of Cirebon decision No. 07 / Pid.Sus.Anak / 2015 / PN.Cbn "by not elaborate on his judgment, the judgment has been deemed to have been considered Litmas PK Bapas.

\footnotetext{
${ }^{13}$ Results Interview with State Court of Cirebon, on February 27, 2020, 13:45 pm
} 
- The value of justice in considering the child's verdict Society Research (Litmas) Society Supervisors (PK) Bapas giving instructions for the judge of the action or what punishment should inflicted on children with attention delinquency, the relationship of parent and child, family's socioeconomic situation, family relations and child on the surrounding environment, but Litmas Bapas PK does not bring positive impact to deliver a fair verdict and best for the child, when the judge makes the Litmas PK Bapas not only as a mere formality for consideration decision.

\subsection{Suggestion}

- The basic idea of social studies report a case handling children better individualization of criminal nature are characteristic of modern flow that adopts a balance between the elements of criminal acts (objective) and actors (subjective) and also adopts the Treatment of Individual Sanction in because before the child was sentenced to advance in meticulous about the background of the offenses are committed as well as the background of social and economic as well as state of the environment children, should be implemented in law changes SPPA clearly so Litmas PK Bapas not only serve as the formal requirements of children in decisions of judges.

- Should be formed institution supervisory judge assigned to judge that the judge's ruling the child can be expressed as the decision null and void, and the judge supervision should stipulate that convicted child can not be executed by the public prosecutor, because the public prosecutor not only as executor but also the (institutions) which are assigned to the indictment, the accused child.

\section{References}

[1] Lukman Hakim and Nainggolan 2006, "Masalah Perlindungan Hukum Terhadap Anak", Jurnal Equality, Vol. 10, No. 2, August 2006, p. 90. See also Dewi Nurul Musjtari, "Memberikan Hak Memilih Agama Sebagai Upaya Perlindungan Anak", Jurnal Konstitusi, Vol. 3, No. 2, May 2006

[2] Mardjono Reksodiputro, 1997, Kriminologi dan Sistem Peradilan Pidana, Pusat Pelayanan Keadilan dan Pengabdian Hukum University of Indonesia, Jakarta.

[3] Muladi, and Barda Nawawi Arief, 1992, Bunga Rampai Hukum Pidana, Alumni, Bandung

[4] Purniati, tt, Analisa Situasi Sistem Peradilan Pidana Anak (Juvenile Justice System) di Indonesia, Departemen Kriminologi Fakultas IImu Sosial dan Politik University of Indonesia, Depok

[5] Romi Asmara, et al., 2008“Kejahatan Kesusilaan Terhadap Ana (Suatu Tinjauan Perlindungan Hukum Terhadap Anak Perempuan Korban Kejahatan Kesusilaan Di Kota Lhokseumawe)", Jurnal Pasai , Vol. II, No. 2, September 2008

[6] Romli Atmasasmita, 1985, Problem Kenakalan Anak (Remaja), Armico, Bandung

[7] Soejono and Abdurahman, 1999, Metode Penelitian, Rieneka Citra, Jakarta

[8] Soerjono Soekanto, 1986, Pengantar Penelitian Hukum, University of Indonesia Press, Jakarta

[9] Sudarto, 1996, Kapita Selekta Hukum Pidana, Alumni, Bandung 